\title{
PERANCANGAN DAN PEMBUATAN VISUAL NOVEL SEJARAH KH. AHMAD DAHLAN SEBAGAI MEDIA PEMBELAJARAN BERBASIS ANDROID
}

\author{
${ }^{1)}$ Imam Adli, ${ }^{2)}$ HarunMukhtar, ${ }^{3)}$ Januar Al Amien \\ 1,2,3)Teknik Informatika Universitas Muhammadiyah Riau \\ 1,2,3)J1. KH. Ahmad Dahlan No. 88, Sukajadi, Kota Pekanbaru \\ E-Mail :.mam.adli@student.umri.ac.id,harunmukhtar@umri.ac.id,januaralamien@umri.ac.id
}

\begin{abstract}
ABSTRAK
KH. Ahmad Dahlan adalah salah satu tokoh penting dan juga pendiri dari Muhammadyah. Karena beliau adalah tokoh penting dalam Muhammadiyah, maka dari itu akan sangat disayangkan jika mahasiswa itu sendiri tidak mengenal siapa itu Ahmad Dahlan. Maka dari itu dibuat sebuah media yang bisa membantu Mahasiswa untuk memahami bagaimana sosok Ahmad Dahlan yaitu dengan menggunakan media game. Game yang akan digunakan adalah game dengan jenis visual novel. Visual novel terdiri dari cerita, gambar, dan suara yang bisa membantu dalam proses pembelajaran. Game ini akan dibuat menggunakan software Ren'Py untuk membuat visual novel menggunakan bahasa pemrograman Python. Pembuatan game ini menggunakan metode MDLC, yaitu terdiri dari konsep, desain, pengumpulan material, penyusunan dan pembuatan, uji coba, kemudian menyebar luaskan. Setelah semua tahapan selesai, maka didapatlah hasil bahwa game ini ternyata mampu memceritakan, dan memberikan pembelajaran mengenai Ahmad Dahlan.
\end{abstract}

Kata Kunci : KH. Ahmad Dahlan, Game Edukasi, Visual Novel, MDCL

\begin{abstract}
KH. Ahmad Dahlan is one of the important figures and also the founder of Muhammadyah. Since he is an important figure in the Muhammadiyah, it would be unfortunate if the student themselves did not know who it was Ahmad Dahlan. Thus created a media that can help students to understand how the figure of Ahmad Dahlan is by using the game media. The game to be used is a game with a novel visual type. Visual novels consist of stories, pictures, and sounds that can help in the learning process. This game will be created using Ren'Py software to create a visual novel using the Python programming language. Making this game using the MDLC method, which consists of the concept, design, material collection, preparation and manufacture, testing, and then spread. After all the stages are completed, then got the results that this game was able to tell, and provide learning about Ahmad Dahlan.
\end{abstract}

Keyword : KH. Ahmad Dahlan, Education Game, Ren'Py, Visual Novel, MDLC

\section{PENDAHULUAN}

KH. Ahmad Dahlan adalah salah satu tokoh penting dan juga pendiri dari Muhammadyah. Muhammadiyah sebagai sebuah persyarikatan Islam yang didirikan oleh KH. Ahmad Dahlan pada tanggal 8 Dzulhijah tahun 1330 Hijriah bertetapan dengan tanggal 18 November 1912 di Yogyakarta, bertujuan untuk menegakkan dan menjunjung tinggi ajaran agama Islam sehingga terwujud masyarakat Islam yang sebenar-benarnya [6].

Penulis ingin mengetahui apakah mahasiswa Fakultas Ilmu Komputer Universitas Muhammadiyah Riau sudah mengetahui sejarah dari KH. Ahmad Dahlan. Oleh karena itu, penulis membuat kuisioner untuk mengetahui apakah para mahasiswa sudah mengetahuinya atau belum.

Setelah dilakukannya pengumpulan data melalui kuisioner, maka didapatkan data yaitu 91 dari 100 orang mahasiswa tersebut belum mengetahui sejarah KH. Ahmad Dahlan. Hal ini sangat memprihatinkan karena KH. Ahmad Dahlan adalah pendiri dari Muhammadiyah. Sebagai mahasiswa Universitas Muhammadiyah, sudah sepantasnya kita mengetahui sosok $\mathrm{KH}$. Ahmad Dahlan. Seandainya hal ini terus terjadi kedepannya, maka dikhawatirkan 
para mahasiswa kedepannya tidak mengenal sama sekali siapa itu KH. Ahmad Dahlan.

Mahasiswa sebagai sumber daya manusia Indonesia sangat dibutuhkan ide dan pendapatnya untuk membangun negeri ini. Kualitas SDM ini sangat terkait dengan minat membaca yang dimiliki mahasiswa. Kebiasaan membaca tidak hanya berkaitan dengan proses belajar mengajar saja, tetapi juga dapat membentuk kepribadian individu dengan menghayati hasil bacaannya. Hasil dari kebiasaan membaca tersebut, maka Singapura dan Malaysia menurut laporan Human Development Index (HDI) 2004, dari 175 negara, tingkat pendidikan Singapura berada di urutan ke-25 dan Malaysia di urutan ke-58. Sedangkan tingkat pendidikan Indonesia berada pada peringkat 111 dari 175 negara.

Sedangkan kualitas manusia Indonesia jauh lebih rendah dari Brunei (33), Thailand (76), dan Filipina (83), bahkan lebih rendah dari negara "terbelakang" seperti Kirgistan (110), Guinea-Khatulistiwa (109), dan Aljazair (108).

Pembelajaran sejarah sebagai bagian dari pendidikan dan bagian dari ilmu sejarah memiliki potensi penting dalam memberikan sumbangan terhadap proses pembangunan bangsa, pendidikan nasional bangsa Indonesia yang sedang mengalami perubahan-perubahan menuju ke arah masyarakat Indonesia modern memerlukan persiapan dan pembinaan generasi muda yang akan menjadi pendukung pada masa depan dan dalam hal ini adalah peserta didik sebagai bagian dari generasi muda [3].

Berdasarkan pernyataan diatas, ilmu sejarah memiliki potensi tinggi dalam pembangunan bangsa. Salah satu alat yang digunakan untuk pembelajaran salah satunya adalah media cetak, sedangkan BPS tahun 2006 mempublikasikan, membaca bagi masyarakat Indonesia belum menjadikan kegiatan sebagai sumber utuk mendapatkan informasi. Masyarakat lebih memilih menonton televisi $(85,9 \%)$ dan mendengarkan radio $(40,3 \%)$ daripada membaca $(23,5 \%)$. Artinya, membaca untuk mendapatkan informasi baru dilakukan oleh 23,5\% dari total penduduk Indonesia. Hasil pengitungan secara kuantitatif yang dilakukan Siswati (2010) menyatakan bahwa dari 92 orang mahasiswa, hanya $20 \%$ orang saja yang menyukai sejarah. Hal ini di karenakan mahasiswa pada saat ini malas membaca.

Media pembelajaran adalah sesuatu yang digunakan untuk menyampaikan materi atau informasi yang akan diajarkan dalam kegiatan belajar agar proses belajar berhasil. Berdasarkan pernyataan tersebut, maka dibutuhkan sebuah media pembelajaran yang mampu untuk menyampaikan materi atau informasi mengenai sejarah KH. Ahmad Dahlan sehingga proses belajar berhasil [19].

Menurut penelitian yang telah dilakukan oleh Wijaya, Panama, \& Erina (2011, hal. 60-61) menyebutkan media yang diminati responden dalam mempelajari Sejarah adalah teks $(6,3 \%)$, gambar $(10,3 \%)$, animasi $(16,6 \%)$, video $(29,1 \%)$, game $(32,6 \%)$ dan lainnya $(5,1 \%)$. Hal tersebut menunjukkan bahwa peserta didik menganggap bahwa melalui permainan, materi Sejarah dapat lebih mudah untuk dipahami dan dihapalkan. Berdasarkan teori ini, maka dirancanglah sebuah game edukasi yang dapat meningkatkan pengetahuan mahasiswa.

Aplikasi Android saat ini sedang populer dan menjadi salah satu sistem aplikasi yang paling banyak digunakan di dunia saat ini.[8]

Salah satu genre game yang dapat digunakan sebagai media pembelajaran adalah visual novel. Sebuah visual novel dapat digunakan sebagai alternatif pembelajaran dari suatu hal, atau visual 
novel bisa menimbulkan minat untuk mengetahui sesuatu tema yang diangkat pada sejarah.[9]

Game dengan genre visual novel ini patut dikembangkan, karena visual novel ini lebih banyak dikembangkan di Jepang. Berdasarkan informasi yang dilansirkan pada www.vice.com bahwa " $99 \%$ of all visual novels remain untranslated, and the average fan translation usually takes around a year and $a$ half to complete". Hal ini menyebabkan visual novel masih belum terlalu banyak dikenal di luar Jepang. Visual novel masih belum banyak di kenal di kalangan masyarakat Indonesia.[18]

\section{Rumusan Masalah}

Dari latar belakang masalah, didapatkan rumusan masalah, yaitu bagaimana membuat game edukasi tentang sejarah KH. Ahmad Dahlan dengan Visual Novel.

\section{Tujuan Penelitian}

Adapun Tujuan dari penelitian ini adalah :

1. Menghasilkan sebuah game yang dapat digunakan sebagai media edukasi.

2. Membantu mahasiswa yang malas membaca buku dalam mengetahui sejarah.

\section{KH.Ahmad Dahlan}

KH. Ahmad Dahlan merupakan salah satu ulama Nusantara yang termasyhur. Dengan organisasi Muhammadiyah yang didirikan, beliau menyiarkan agama Islam ke seluruh penjuru tanah air. KH. Ahmad Dahlan juga sangat disegani dikalangan pengikutnya, meski diawal-awal dakwahnya selalu mendapatkan banyak cercaan dari orang-orang di sekitarnya. Beliau dengan istiqomah dan teladan terus berusaha memurnikan ajaran agama islam yang bercampur dengan ritual-ritual takhayul.
Baginya, agama islam haruslah sesuai dengan al-Qur'an dan hadist.

KH. Ahmad Dahlan lahir pada tahun 1869 di kampung Kauman, Yogyakarta. Beliau memiliki nama kecil Muhammad Darwis. Ayahnya bernama KH. Abu Bakar bin Kiai Sulaiman, seorang khatib tetap di masjid Agung. Sedangkan ibunya bernama Siti Aminah binti KH. Ibrahim, seorang penghulu besar di Yogyakarta. KH. Ahmad Dahlan merupakan anak keempat dari tujuh bersaudara yang semua saudaranya adalah perempuan, kecuali adiknya yang paling bungsu. [14]

\section{Game}

Game pada awalnya dibuat untuk tujuan kesengangan dan hiburan, tapi mereka baru-baru ini mengarahkannya pada hal-hal yang memberikan keuntungan lebih pada user, sehingga disebut dengan game serius. Game yang serius menggunakan pendidikan untuk memasukan sesuatu yang berguna melalui pengalaman dalam bermain game. Game edukasi adalah permainan yang dirancang atau dibuat untuk merangsang daya pikir termasuk meningkatkan konsentrasi dan memecahkan masalah. Molina, masih pada penelitian yang sama menambahkan bahwa, edugame adalah sebuah permainan yang digunakan dalam proses pembelajaran dan dalam permainan tersebut mengandung unsur mendidik atau nilai-nilai pendidikan. Game mempunyai kontribusi untuk memotivasi dalam pembelajaran. Permainan dapat merangsang untuk belajar sesuatu yang baru dan dapat memberikan pengalaman yang menyenangkan bagi peserta didik karena terjalin interaksi antar pemain, selain itu dapat memberikan dasar bagi pencapaian macam-macam keterampilan untuk memecahkan masalah. Namun jika pelaksanaan permainan tidak dipantau oleh 
guru akan terjadi kesalahan dalam teknis pelaksanaan dikarenakan asyik atau tidak paham aturan. Selain itu permainan yang kurang menantang atau susah akan mengakibatkan peserta didik cepat bosan.

\section{Renpy}

Pada pembuatan game ini, akan digunakan software yaitu Ren'Py. Menurut situs http://www.renpy.org/, Ren'Py adalah sebuah framework permainan di dalam bahasa pemrograman Python yang memiliki berbagai macam fitur lengkap di dalam pembuatan aplikasi lain seperti pembelajaran interaktif.

\section{Photoshop}

Adobe Photoshop, atau biasa disebut Photoshop, adalah perangkat lunak editor citra buatan Adobe Systems yang dikhususkan untuk pengeditan foto/gambar dan pembuatan efek. Perangkat lunak ini banyak digunakan oleh fotografer digital dan perusahaan iklan sehingga dianggap sebagai pemimpin pasar (market leader) untuk perangkat lunak pengolah gambar/foto, dan, bersama Adobe Acrobat, dianggap sebagai produk terbaik yang pernah diproduksi oleh Adobe Systems. Versi kedelapan aplikasi ini disebut dengan nama Photoshop CS (Creative Suite), versi sembilan disebut Adobe Photoshop CS2, versi sepuluh disebut Adobe Photoshop CS3, versi kesebelas adalah Adobe Photoshop CS4, versi keduabelas adalah Adobe Photoshop CS5, dan versi terbaru adalah Adobe Photoshop CC.

Photoshop tersedia untuk Microsoft Windows, Mac OS X, dan Mac OS; versi 9 ke atas juga dapat digunakan oleh sistem operasi lain seperti Linux dengan bantuan perangkat lunak tertentu seperti CrossOver. Pada tahun 1987, Thomas Knoll, mahasiswa $\mathrm{PhD}$ di Universitas Michigan, mulai menulis sebuah program pada Macintosh Plus-nya untuk menampilkan gambar grayscale pada layar monokrom. Program ini, yang disebut Display, menarik perhatian saudaranya John Knoll, seorang karyawan di Industrial Light \& Magic, yang merekomendasikan Thomas agar mengubah programnya menjadi program penyunting gambar penuh. Thomas mengambil enam bulan istirahat dari studi pada tahun 1988 untuk berkolaborasi dengan saudaranya pada program itu, yang telah diubah namanya menjadi ImagePro. Setelah tahun itu, Thomas mengubah nama programnya menjadi Photoshop dan bekerja dalam jangka pendek dengan produsen scanner Barneyscan untuk mendistribusikan salinan dari program tersebut dengan slide scanner; "total sekitar 200 salinan Photoshop telah dikirimkan" dengan cara ini.

Selama waktu itu, John bepergian ke Silicon Valley di California dan memberikan demonstrasi program itu kepada insinyur di Apple Computer Inc. dan Russell Brown, direktur seni di Adobe. Kedua demonstrasi itu berhasil, dan Adobe memutuskan untuk membeli lisensi untuk mendistribusikan pada bulan September 1988. Sementara John bekerja pada plug-in di California, Thomas tetap di Ann Arbor untuk menulis kode program. Photoshop 1.0 dirilis pada 1990 khusus untuk Macintosh. Meskipun pada awalnya Photoshop dirancang untuk menyunting gambar untuk cetakan berbasiskertas, Photoshop yang ada saat ini juga dapat digunakan untuk memproduksi gambar untuk World Wide Web. Beberapa versi terakhir juga menyertakan aplikasi tambahan, Adobe ImageReady, untuk keperluan tersebut. Photoshop juga memiliki hubungan erat dengan beberapa perangkat lunak penyunting media, animasi, dan authoring buatan-Adobe lainnya.

File format asli Photoshop, .PSD, dapat diekspor ke dan dari Adobe 
ImageReady. Adobe Illustrator, Adobe Premiere Pro, After Effects dan Adobe Encore DVD untuk membuat DVD profesional, menyediakan penyuntingan gambar non-linear dan layanan special effect seperti background, tekstur, dan lain-lain untuk keperluan televisi, film, dan situs web. Sebagai contoh, Photoshop CS dapat digunakan untuk membuat menu dan tombol (button) DVD. Versi yang dirilis pada tahun 2005, adalah versi 9. Program ini dipasarkan dengan nama "Photoshop CS2." "CS" merefleksikan integrasi produk Photoshop dengan aplikasi "Creative Suite buatan Adobe dan disebut "2" karena program ini adalah versi rilis ke-2 sejak Adobe mengintegrasikan kedua produknya. Ada beberapa pada tambahan pada Photoshop CS2 seperti multiple layer selecting dan "warp," versi kurva dari transform tool dan color replacement tool, yang sebelumnya hadir sebagai plug-in 8BF. Untuk para penggemar fotografi, Adobe menyediakan filter "reduce grain" (mengurangi grain) yang dapat membantu mengoptimalkan foto yang diambil pada kondisi kekurangan cahaya. Untuk "memperjelas" perbedaan produk CS dengan produk-produk Photoshop sebelumnya, Adobe menghilangkan lambang mata Photshop, yang dipresentasikan dalam bentuk yang berbeda-beda sejak versi 3 sampai versi 7 .

Photshop CS dan CS2 kini menggunakan bulu sebagai ikon dan bentuk identifikasinya. Versi beta Photoshop CS3 telah dirilis untuk pengguna CS2 pada tanggal 15 Desember 2006. Berbeda dengan Photoshop CS dan CS2 yang menggunakan bulu sebagai logonya, Logo untuk edisi ketiga ini berbentuk tipografi, dengan huruf 'Ps' berwarna putih dan berlatar belakang biru-gradien. Versi terakhirnya dilengkapi dengan Adobe Camera RAW, sebuah plugin yang dikembangkan oleh Thomas Knoll yang dapat membaca beberapa format file RAW dari kamera digital dan mengimpornya langsung ke Photoshop. Versi awal RAW plugin ini juga tersedia untuk Photoshop 7.0.1 dengan tambahan biaya \$99 USD. Secara Photoshop adalah sebuah program penyunting gambar standar industri yang ditujukan untuk para profsional raster grafik, harga yang ditawarkan pun cukup tinggi; kira-kira US\$600. Keadaan ini memancing beberapa programer untuk merancang peralatan grafik (graphics tools) dengan harga yang lebih terjangkau. Untuk menghadapi persaingan ini, dan untuk menghadapi pembajakan produknya, Adobe memperkenalkan Photoshop Elements, sebuah versi lain dari Photoshop yang lebih minimalis, dengan harga terjangkau; di bawah US\$100. Produk ini ditujukan untuk pengguna rumahan dan menghilangkan beberapa fitur profesional.

\section{Visual Novel}

Visual novel adalah game yang menggunakan gaya penceritaan seperti halnya sebuah novel, divisualisasi dengan gambar berupa tokoh dari novel tersebut, gambar kejadian-kejadian yang patut divisualkan, dan gambar pemandangan dengan background dimana karakterkarakter itu sedang berada.

\section{Android}

Android adalah sistem operasi berbasis Linux yang dirancang untuk perangkat bergerak layar sentuh seperti telepon pintar dan komputer tablet. Android awalnya dikembangkan oleh Android, Inc., dengan dukungan finansial dari Google, yang kemudian membelinya pada tahun 2005. Sistem operasi ini dirilis secara resmi pada tahun 2007, bersamaan dengan didirikannya Open Handset Alliance, konsorsium dari perusahaan-perusahaan 
perangkat keras, perangkat lunak, dan telekomunikasi yang bertujuan untuk memajukan standar terbuka perangkat seluler. Ponsel Android pertama mulai dijual pada bulan Oktober 2008.

Android adalah sistem operasi dengan sumber terbuka, dan Google merilis kodenya di bawah Lisensi Apache. Android memiliki sejumlah besar komunitas pengembang aplikasi yang memperluas fungsionalitas perangkat, umumnya ditulis dalam versi kustomisasi bahasa pemrograman Java. Pada bulan Oktober 2013, ada lebih dari satu juta aplikasi yang tersedia untuk Android, dan sekitar 50 miliar aplikasi telah diunduh dari Google Play, toko aplikasi utama Android. Sebuah survei pada bulan April-Mei 2013 menemukan bahwa Android adalah platform paling populer bagi para pengembang, digunakan oleh $71 \%$ pengembang aplikasi bergerak. Di Google I/O 2014, Google melaporkan terdapat lebih dari satu miliar pengguna aktif bulanan Android, meningkat dari 583 juta pada bulan Juni 2013.

Faktor-faktor di atas telah memberikan kontribusi terhadap perkembangan Android, menjadikannya sebagai sistem operasi telepon pintar yang paling banyak digunakan di dunia, mengalahkan Symbian pada tahun 2010. Android juga menjadi pilihan bagi perusahaan teknologi yang menginginkan sistem operasi berbiaya rendah, bisa dikustomisasi, dan ringan untuk perangkat berteknologi tinggi tanpa harus mengembangkannya dari awal. Sifat Android yang terbuka juga telah mendorong munculnya sejumlah besar komunitas pengembang aplikasi untuk menggunakan kode sumber terbuka sebagai dasar proyek pembuatan aplikasi, dengan menambahkan fitur-fitur baru bagi pengguna tingkat lanjut atau mengoperasikan Android pada perangkat yang secara resmi dirilis dengan menggunakan sistem operasi lain.

Pada November 2013, Android menguasai pangsa pasar telepon pintar global, yang dipimpin oleh produk-produk Samsung, dengan persentase $64 \%$ pada bulan Maret 2013. Pada Juli 2013, terdapat 11.868 perangkat Android berbeda dengan beragam versi. Keberhasilan sistem operasi ini juga menjadikannya sebagai target ligitasi paten "perang telepon pintar" antar perusahaan-perusahaan teknologi. Hingga bulan Mei 2013, total 900 juta perangkat Android telah diaktifkan di seluruh dunia, dan 48 miliar aplikasi telah dipasang dari Google Play.

Tidak hanya menjadi sistem operasi di smartphone, saat ini Android menjadi pesaing utama dari Apple pada sistem operasi Tablet PC. Pesatnya pertumbuhan Android selain factor yang disebutkan diatas adalah karena Android itu sendiri adalah platform yang sangat lengkap baik itu sistem operasinya, Aplikasi dan Tool Pengembangan, Market aplikasi Android serta dukungan yang sangat tinggi dari komunitas Open Source di dunia, sehingga Android terus berkembang pesat baik dari segi teknologi maupun dari segi jumlah device yang ada didunia. [15]

\section{Ren'Py Android Packaging Tool}

Ren'Py Android Packaging Tool (RAPT) is a program, downloaded separately from Ren'Py, that creates an Android package for testing or release purposes.

\section{Python}

Python adalah bahasa pemrograman yang berfokus pada tingkat keterbacaan kode. Python diklaim sebagai bahasa yang menggabungkan kapabilitas, kemampuan, dengan sintaksis kode yang sangat jelas, dan 
dilengkapi dengan fungsionalitas pustaka standar yang besar serta komprehensif.

Salah satu fitur yang tersedia pada python adalah sebagai bahasa pemrograman dinamis yang dilengkapi dengan manajemen memori otomatis. Seperti halnya pada bahasa pemrograman dinamis lainnya, python umumnya digunakan sebagai bahasa skrip meski pada praktiknya penggunaan bahasa ini lebih luas mencakup konteks pemanfaatan yang umumnya tidak dilakukan dengan menggunakan bahasa skrip. Python dapat digunakan untuk berbagai keperluan pengembangan perangkat lunak dan dapat berjalan di berbagai platform sistem operasi.

Saat ini kode python dapat dijalankan di berbagai platform sistem operasi, beberapa di antaranya adalah:
a. Linux/Unix
b. Windows
c. Mac OS X
d. Java Virtual Machine
e. $\mathrm{OS} / 2$
f. Amiga
g. Palm
h. Symbian

Python didistribusikan dengan beberapa lisensi yang berbeda dari beberapa versi. Namun pada prinsipnya Python dapat diperoleh dan dipergunakan secara bebas, bahkan untuk kepentingan komersial. Bahasa pemrograman Python ini memiliki efisiensi tinggi untuk struktur data level tinggi, pemrograman berorientasi objek lebih sederhana tetapi efektif, dapat bekerja pada multi platform, dan dapat digabungkan dengan bahasa pemrograman lain untuk menghasilkan aplikasi yang diinginkan [4].

\section{Blackbox Testing}

Black-box testing adalah metode pengujian perangkat lunak yang tes fungsionalitas dari aplikasi. Metode ujicoba blackbox memfokuskan pada keperluan fungsional dari software.

\section{METODE}

Metodologi penelitian adalah proses atau cara ilmiah untuk mendapatkan data yang akan digunakan untuk keperluan penelitian. Metodologi juga merupakan analisis teoretis mengenai suatu cara atau metode. Penelitian merupakan suatu penyelidikan yang sistematis untuk meningkatkan sejumlah pengetahuan, juga merupakan suatu usaha yang sistematis dan terorganisasi untuk menyelidiki masalah tertentu yang memerlukan jawaban.

Hakikat penelitian dapat dipahami dengan mempelajari berbagai aspek yang mendorong penelitian untuk melakukan penelitian. Setiap orang mempunyai motivasi yang berbeda, di antaranya dipengaruhi oleh tujuan dan profesi masingmasing. Motivasi dan tujuan penelitian secara umum pada dasarnya adalah sama, yaitu bahwa penelitian merupakan refleksi dari keinginan manusia yang selalu berusaha untuk mengetahui sesuatu. Keinginan untuk memperoleh dan mengembangkan pengetahuan merupakan kebutuhan dasar manusia yang umumnya menjadi motivasi untuk melakukan penelitian.

Dari waktu ke waktu pembelajaran selalu mengalami perkembangan. Berbagai model, metode, media serta hal-hal lain yang baru muncul dan dipergunakan dalam pembelajaran. Perkembangan multimedia juga termasuk digunakan dalam pembelajaran. Penggunaan multimedia dalam pembelajaran dapat menggantikan metode pembelajaran secara konvensional menjadi lebih menarik. Penggunaan dan 
perpaduan gambar, video dan suara dalam multimedia banyak menarik maupun menggugah minat belajar peserta didik ataus siswa. Multimedia juga mampu memudahkan penyampaian materi-materi tertentu kepada siswa dibandingkan dengan cara penyampaian materi lainnya. Namun untuk membuat penggunaan dan materi multimedia yang tepat pada pembelajaran perlu pengembangan khusus, mengingat untuk produksi multimedia diperlukan pengetahuan dan keterampilan dalam menyusun dan membangun materi berbasis multimedia yang baik. Pengembangan multimedia agar dapat dimasukkan dalam pembelajaran harus melalui tahapan-tahapan yang terancang dengan baik dan runtut agar produk multimedia yang dihasilkan memiliki kualitas yang baik dan tepat digunakan dalam pembelajaran.

Metode yang digunakan dalam pengembangan multimedia Interaktif ini adalah Multimedia Development Life Cycle. Multimedia Development Life Cycle adalah yang memiliki 6 tahap yaitu :

\section{Konsep}

Tahapan pertama ini akan dirumuskan konsep dasar dari proyek multimedia yang akan dibuat dan dikembangkan, seperti bagaimana konsep bermain yang akan dilakukan nanti dalam game, bagaimana jalan cerita dari game, dan apa saja yang perlu dipersiapkan dalam pembuatan game nya dan susunan rencana dari konsep itu sendiri. Setelah konsep ini dijalani, barulah melanjutkan tahapan selanjutnya yaitu mulai mendesain.

\section{Desain}

Menggambarkan proses kegiatan yang akan diterapkan dan menjelaskan kebutuhan yang diperlukan agar game ini dapat dirancang dengan baik. Pada tahap ini dilakukan 3 perancangan, yaitu :

\section{a. Storyline}

Storyline merupakan sebuah naskah cerita dalam bentuk teks. Merancang naskah merupakan spesifikasi lengkap dari teks dan narasi dalam aplikasi multimedia. Dalam merancang naskah, analis menetapkan dialog dan urutan elemen-elemen secara rinci.

b. Storyboard

Storyboard adalah naskah yang dituangkan dalam bentuk gambar. Storyboard merupakan serangkaian sketsa dibuat persegi panjang yang menggambarkan suatu alur cerita yang diusulkan untuk aplikasi Multimedia. Proses pembuatan papan cerita dapat memakan waktu lama dan rumit. Banyak film bisu beranggaran besar dibuat menurut papan cerita, sayangnya kebanyakan sudah hilang ketika arsip-arsip studio dikurangi pada tahun 1970-an. Pembuatan papan cerita menjadi populer untuk produksi film aksi hidup selama tahun 1940-an, dan menjadi medium standar untuk pra-visualisasi (previsualization) film-film. Annette Micheloson, kurator pada Pace Gallery, menulis dalam rangka pameran Drawing into Film: Director's Drawings, menganggap tahun 1940-an sampai 1990-an sebagai periode di mana "production design (desain produksi) ditandai secara luas dengan penggunaan papan cerita". Papan cerita sekarang merupakan bagian esensial proses kreatif.

\section{c. Interface}

Antarmuka merupakan mekanisme komunikasi antara pengguna dengan sistem. Antarmuka dapat menerima informasi dari 
pengguna dan memberikan informasi kepada pengguna untuk membantu mengarahkan alur penelusuran masalah sampai ditemukan suatu solusi.

\section{Pengumpulan Materi}

Merupakan proses untuk pengumpulan segala sesuatu yang dibutuhkan dalam proyek. Mengenai materi yang akan disampaikan, kemudian file-file multimedia seperti audio, dan gambar yang akan dimasukkan dalam penyajian proyek multimedia tersebut.

\section{Penyusunan dan Pembuatan}

Assembly adalah waktunya proyek multimedia diproduksi. Materi-materi serta file-file multimedia yang sudah didapat kemudian dirangkai dan disusun sesuai design.

\section{Uji Coba}

Pada tahapan ini, pengujian perangkat lunak merupakan suatu investigasi yang dilakukan untuk mendapatkan informasi mengenai kualitas dari produk atau layanan yang sedang diuji. Pengujian perangkat lunak juga memberikan pandangan mengenai perangkat lunak secara obyektif dan independen, yang bermanfaat dalam operasional bisnis untuk memahami tingkat risiko pada implementasinya. Teknik-teknik pengujian mencakup, namun tidak terbatas pada, proses mengeksekusi suatu bagian program atau keseluruhan aplikasi dengan tujuan untuk menemukan bug perangkat lunak.

\section{Penyebarluasan}

Tahap penggandaan dan penyebaran hasil kepada pengguna. Multimedia perlu dikemas dengan baik sesuai dengan media penyebar luasannya, apakah melalui CD/DVD, download, ataupun media yang lain.

\section{HASIL}

\section{Konsep}

Tahap konsep adalah tahap untuk menentukan tujuan, siapa pengguna program, jenis aplikasi dan tujuan aplikasi. Dalam penelitian ini dibuat sebuah game dengan jenis visual novel yang bertujuan untuk membuat sebuah game yang dapat digunakan sebagai media pembelajaran mengenai sejarah K.H Ahmad Dahlan. Pembelajaran yang akan diberikan pada game ini yaitu menyantuni anak yatim.

Game ini akan dibuka dengan sebuah sambutan kepada player sebelum memasuki cerita dari game ini. Kemudian barulah memasuki intro cerita dimana K.H Ahmad Dahlan lahir, player akan berperan sebagai K.H Ahmad Dahlan dan dari situ dimulailah dialog-dialog antar karakter, dan pada bagian tertentu. Player akan menerima sebuah pilihan pada beberapa point untuk melanjutkan cerita, jika player salah memilih pilihan yang salah maka cerita akan berakhir pada wrong ending, sebaliknya jika player memainkan game tersebut dengan pilihan yang benar maka game tersebut akan mencapai true ending. Game ini juga dilengkapi dengan soal-soal yang akan ditanyakan begitu suatu chapter tersebut telah selesai. Jika player tersebut menjawab dengan salah maka akan muncul pilihan apakah player ingin mengulangi lagi cerita tersebut atau melanjutkan cerita tersebut.

\section{Desain}

Tahap desain adalah menggambarkan proses kegiatan yang akan diterapkan dalam sistem dan menjelaskan kebutuhan yang diperlukan agar sistem dapat berjalan dengan baik serta sesuai. Pada tahap ini dilakukan adalah :

\section{a. Storyline}

Cerita dalam game ini bercerita tentang Muhammad Darwis yaitu adalah salah satu tokoh penting dan 
juga pendiri dari Muhammadyah. Muhammadiyah sebagai sebuah persyarikatan Islam yang didirikan oleh KH. Ahmad Dahlan pada tanggal 8 Dzulhijah tahun 1330 Hijriah bertetapan dengan tanggal 18 November 1912 di Yogyakarta, bertujuan untuk menegakkan dan menjunjung tinggi ajaran agama Islam sehingga terwujud masyarakat Islam yang sebenarbenarnya.

Ada 7 karakter dalam permainan ini, yaitu : Muhammad Darwis/K.H Ahmad Dahlan, Kyai Abu Bakar, ayah dari Muhammad Darwis, Kyai Penghulu, Kyai di Kauman, Rykbestur der, pepatih dalam Sri Sultan Hamengkubuwana VII, Siti Walidah, istri dari Muhammad Darwis, Muhammad Shaleh, saudara Muhammad Darwis, Murid, salah satu murid di Langgar Kidul

Gameplay adalah cara spesifik di mana pemain berinteraksi dengan permainan, dan khususnya dengan permainan video. Gameplay adalah pola yang didefinisikan melalui aturan permainan, hubungan antara pemain dan permainan, tantangan dan mengatasi mereka, plot dan hubungan pemain dengannya. Permainan video gameplay berbeda dari grafis dan elemen audio. Pemain akan mengikuti alur cerita yang disajikan, dalam game ini akan di memakai system choice yaitu memilih. Dimana kita akan menentukan jalan cerita dari tokoh utama tersebut, jika cerita melenceng dari sejarah, maka cerita akan berakhir pada Bad Ending sebaliknya jika pemain memainkan cerita dengan benar maka akan mencapai Good Ending.

\section{b. Storyboard}

Setelah mendapatkan jalan cerita dari game yang akan dibuat, maka yang akan dibuat selanjutnya adalah storyboard nya.

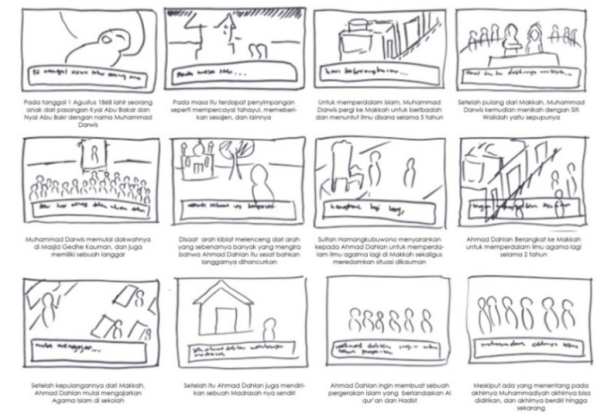

Gambar 5. Storyboard

\section{c. Interface}

Pada interface ini akan menampilkan bagaimana tampilan dari game itu sendiri. Untuk tampilan karakter dan background, ada langkah-langkah yang akan dilakukan, yaitu gambar manual, scan, dan edit photoshop.

\section{Pengumpulan Materi}

Merupakan proses untuk pengumpulan segala sesuatu yang dibutuhkan dalam proyek. Untuk penggunaan audio penulis akan menggunakan audio dengan lisensi gratis untuk dipasang pada game ini.

\section{Penyusunan dan Pembuatan}

Tahap assembly adalah tahap dimana semua objek atau bahan game dipasang dan dibuat menjadi game. Pembuatan aplikasi didasarkan pada tahap design yang telah ditentukan sebelumnya.

\section{a. Membuat Label}

Pernyataan label memungkinkan nama yang diberikan ditugaskan ke titik program. Mereka ada semata-mata untuk dipanggil atau dilompati, 
entah dari naskah Ren'Py, fungsi Python, atau dari layar. Pernyataan label mungkin memiliki blok yang terkait dengannya. Dalam hal ini, kontrol memasuki blok setiap kali pernyataan label tercapai, dan dilanjutkan dengan pernyataan setelah pernyataan label setiap kali akhir blok tercapai.

\section{b. Menulis Dialog Percakapan}

Dalam tahap ini, akan memperlihatkan bagaimana membuat dialog yang dilakukan oleh setiap karakter dalam game ini. Dalam percakapan ini, kita akan menggunakan define yang digunakan untuk mendefinisikan sesuatu. define e $=$ Character ( " Eileen ", who_color $=$ " \#104010 " )

\section{c. Menampilkan Gambar}

Semua gambar dari layar, dan menampilkan satu gambar. Segmen skrip ini mengenalkan dua pernyataan baru. Pernyataan adegan pada baris 6 membersihkan semua gambar dan menampilkan gambar latar belakang. Pernyataan acara pada baris 16 dan 26 menampilkan sprite di atas latar belakang, dan mengubah sprite display masingmasing.

\section{d. Mempuat Pilihan}

Pada bagian ini akan menjelaskan bagaimana membuat menu pilihan pada game. Untuk membuat menu pilihan ini, kita juga harus mempersiapkan 2 label atau lebih, untuk menentukan kemana arah pilihan tersebut. Membuat menu pilihan diawali dengan membuat perintah "menu".

\section{e. Menampilkan Peta}

Cara mudah membuat layar, terutama bagi mereka yang berpikir secara visual adalah membuat peta gambar. Saat membuat peta gambar, pernyataan imagemap digunakan untuk menentukan hingga enam gambar. Gambar hotspot dan hotbar digunakan untuk mengukir area persegi empat dari gambar, dan menerapkan tindakan dan nilai ke area tersebut.

\section{f. Menampilkan Suara}

Untuk menampilkan suara, akan menggunakan 2 perintah, yaitu play music, dan play sound. Play music digunakan jika kita menginginkan sound effect tersebut dapat dimainkan secara berulang ulang, sedangkan play sound digunakan untuk sound effect yang akan dimainkan sekali tanpa adanya proses pengulangan seperti perintah dari play music.

\section{g. Membuat Gallery}

Untuk membuat gallery, pada tahap ini akan menggunakan perintah screen yaitu untuk membuat tampilan ketika menu gallery terpilih. Dan juga untuk menampilkan gambar yang ingin ditambahkan, maka kita akan menggunakan perintah g.image, yaitu untuk memanggil gambar gambar yang akan diletak pada gallery.

Galeri gambar adalah layar yang memungkinkan pemain membuka gambar, lalu melihat gambar itu. Layar memiliki satu atau lebih tombol yang terkait dengannya, dan setiap tombol memiliki satu atau lebih gambar yang terkait. Tombol dan gambar juga memiliki kondisi yang 
menentukan apakah mereka telah terkunci.

Galeri gambar dikelola oleh contoh kelas Galeri. Sebuah contoh tunggal dari kelas galeri dapat dibagi di antara beberapa layar galeri gambar. Galeri memiliki satu atau lebih tombol yang terkait dengannya, sebuah tombol memiliki satu atau lebih gambar yang terkait dengannya, dan setiap gambar memiliki satu atau lebih serangan yang terkait dengannya. Kondisi bisa diberikan ke tombol dan gambar. Tombol tidak terkunci bila semua kondisi yang terkait dengannya terpenuhi dan setidaknya satu gambar yang dikaitkan dengan tombol itu tidak terkunci. Gambar tidak terkunci bila semua kondisi yang terkait terpenuhi.

\section{Uji Coba}

Black box testing adalah pengujian yang dilakukan hanya mengamati hasil eksekusi melalui data uji dan memeriksa fungsional dari perangkat lunak. Jadi dianalogikan seperti kita melihat suatu koatak hitam, kit hanya bisa melihat penampilan luarnya saja, tanpa tau ada apa dibalik bungkus hitam nya. Sama seperti pengujian black box, mengevaluasi hanya dari tampilan luarnya, fungsionalitas nya tanpa mengetahui apa sesungguhnya yang terjadi dalam proses detilnya.

Black Box pengujian adalah metode pengujian perangkat lunak yang menguji fungsionalitas aplikasi yang bertentangan dengan struktur internal atau kerja. Pengetahuan khusus dari kode aplikasi / struktur internal dan pengetahuan pemrograman pada umumnya tidak diperlukan. Uji kasus dibangun di sekitar spesifikasi dan persyaratan, yakni, aplikasi apa yang seharusnya dilakukan. Menggunakan deskripsi eksternal perangkat lunak, termasuk spesifikasi, persyaratan, dan desain untuk menurunkan uji kasus. Tes ini dapat menjadi fungsional atau nonfungsional, meskipun biasanya fungsional. Perancang uji memilih input yang valid dan tidak valid dan menentukan output yang benar. Tidak ada pengetahuan tentang struktur internal benda uji itu. Metode uji dapat diterapkan pada semua tingkat pengujian perangkat lunak: unit, integrasi, fungsional, sistem dan penerimaan. Ini biasanya terdiri dari kebanyakan jika tidak semua pengujian pada tingkat yang lebih tinggi, tetapi juga bisa mendominasi unit testing juga.

Uji coba yang dilakukan terhadap Game ini yaitu black box testing dan menggunakan metode kuisioner dimana penilaian dapat dilakukan selama proses pengetesan dilakukan. Responden yang digunakan disini menggunakan sebanyak 10 orang mahasiswa.

Pengujian pada Black Box berusaha menemukan kesalahan seperti:

a. Fungsi-fungsi yang tidak benar atau hilang

b. Kesalahan interface

c. Kesalahan dalam struktur data atau akses database eksternal

d. Kesalahan kinerja

e. Inisialisasi dan kesalahan terminasi

\section{Penyebarluasan}

Pada tahap ini akan dilakukan tahap distribution yaitu tahap penyebar luasan game agar game ini bisa dinikmati oleh yang lainnya. Untuk mendapatkan game ini, game ini nantinya akan di unggah ke play store dengan nama Muhammadiyah 
vn game.

\section{KESIMPULAN}

Berdasarkan hasil penelitian yang telah dilakukan dapat disimpulkan bahwa penelitian ini telah berhasil membuat game edukasi yang menceritakan sejarah kehidupan KH. Ahmad Dahlan dengan dengan Visual Novel.

\section{DAFTAR PUSTAKA}

[1] Dewi, G. P. (2012). Pengembangan Game Edukasi Pengenalan Nama Hewan Dalam Bahasa Inggris Sebagai Media Pembelajaran Siswa SD Berbasis Macromadia Flash. Yogyakarta: Fakultas Teknik Universitas Negeri Yogyakarta.

[2] Dr. Imam Dui Agusalim, D. M. (2015). Developing Visual Novel Game of English Conversation for DEP EEPIS. Journal of Education and Practice, 113.

[3] Dr. Rudy Gunawan, M. (2012). PEMBELAJARAN SEJARAH BERBASIS PERMAINAN TRADISIONAL BETAWI. 2. Jl. Prof Sudharto. SH. (2010). MINAT MEMBACA PADA MAHASISWA. Semarang: UNDIP.

[4] Kurniawan, H., Setiyono, B., \& Isnanto, R. R. (2011). Aplikasi Penjawawab Pesan Singkat Automatis dengan Bahasa Python. Semarang: Halim Kurniawan.

[5] Lutfiyatun, E. (2015). Pengembangan Media Game Edukasi Bebasis Adobe Flash CS5 Pada Keterampilan Menulis Bahasa Arab Untuk Siswa Kelas VIII MTs. Semarang: Fakultas Bahasa dan Seni Universitas Negri Semarang.

[6] Muhammadiyah, P. W. (2008). Pendidikan Kemuhammadiyahan.
Yogyakarta: Majelis Pendidikan Dasar dan Menengah.

[7] Munandri, D. R. (2012). Pembuatan Visual Novel dengan Cafe Minigame Menggunakan Ren'py. Yogyakarta: Sekolah Tinggi Manajemen Informatika dan Komputer AMIKOM.

[8] Murtiwiyati, G. L. (2013). Jurnal Ilmiah Komputasi Komputer \& Sistem Informasi. Rancang Bangun Aplikasi Pembelajaran Budaya Indonesia Untuk Anak Sekolah Dasar Berbasis, 1.

[9] Pamungkas, W., Yuangga, D., \& Eka, I. G. (2015). Pembuatan Game Visual Novel "Highschool Go! Love On!" Menggunakan Ren'py. Yogyakarta: Sekolah Tinggi Manajemen Informatika dan Komputer.

[10]Prasetya, I. A., Tursina, \& Safriadi, N. (2015). Penerapan Visual Novel Dari Cerita Rakyat Asal Usul Kota Pontianak. Jurnal Sistem dan Teknologi Informasi, 1.

[11]Putra, R. C. (2016). Pembuatan Game Edukasi Pintar Memilih Sampah Berbasis Android. Surakarta: Fakultas Komunikasi dan Informasi Universitas Muhammadiyah Surakarta.

[12]Putranto, A. (2012). Pengembangan Game Edukasi Klasifikasi Hewan Menggunakan Adobe Flash Professional CS5 Sebagai Media Pembelajaran Biologi Kelas VII Di SMPN 15 Yogyakarta. Yogyakarta: Fakultas Teknik Universitas Negeri Yogyakarta.

[13]Rifai, W. A. (2015). Pengembangan Game Edukasi Lingkungan Berbasis Android. Yogyakarta: Fakultas Teknik Universitas Negeri Yogyakarta.

[14]Rokhim, N. (2015). Kiai-Kiai Kharismatik \& Fenomenal. Yogyakarta: IRCiSoD.

[15] Safaat, N. (2015). Android : Pemograman Aplikasi Mobile 
Smartphone dan Tablet PC Berbasis Android. Bandung: Informatika.

[16]Suindarti. (2011). Game Edukasi Meningkatkan Daya Ingat Anak "Bermain Bersama Dido" dengan Macromadia Director". Yogyakarta: Jurusan Sistem Informasi Sekolah Tinggi Manajemen Informatika dan Komputer.

[17] Vika Fitratunnany Insanittaqwa, I. K. (2014). Game Edukasi 'Simulasi Haji' Menggunakan Ren'Py pada Perangkat Android untuk Simulasi Perjalanan Ibadah Haji. JURNAL TEKNIK POMITS , 52.

[18] Wibowo, F. Y. (2016). Pembuatan Game Cerita Bergambar Berbasis Desktop. Yogyakarta: Sekolah Tinggi Manajemen Informatika Dan Komputer.

[19]Wulandari, A. D. (2012). Game Edukatif Sejarah Komputer Menggunakan Role Playing Game Sebagai Media Pembelajaran Di SMP Negri 2 Kalibawang. Yookyakarta: Fakultas Teknik Universitas Negri Yogyakarta. 